\title{
Asymmetric Response of Public Utility Stock Returns Volatility to Up and Down Markets and Deregulation
}

\author{
Richard A. Michelfelder \\ School of Business, Rutgers University, Camden, NJ, USA \\ Email: richmich@camden.rutgers.edu
}

How to cite this paper: Michelfelder, R.A. (2018) Asymmetric Response of Public Utility Stock Returns Volatility to Up and Down Markets and Deregulation. Journal of Mathematical Finance, 8, 576-598. https://doi.org/10.4236/jmf.2018.83037

Received: April 8, 2018

Accepted: August 13, 2018

Published: August 16, 2018

Copyright $\odot 2018$ by author and Scientific Research Publishing Inc. This work is licensed under the Creative Commons Attribution International License (CC BY 4.0).

http://creativecommons.org/licenses/by/4.0/

c) (i) Open Access

\begin{abstract}
This investigation researches how industry institutional regimes can affect the pattern and volatility of stock prices and returns. This paper searches for information signals of regulatory policy in US electric public utility company stock returns and also tests for volatility changes from the buffering effect from deregulation. Utility stock returns asymmetry in up and down markets is modeled for evidence of investor information signals of regulatory behavior. Lax regulation should lead to utility stock returns that react strongly to up markets due to weakly-constrained expected upside profits. Utility stock returns should have a small response to down markets. Stringent regulation should generate the opposite result. Since stock returns distributions typically have skewness and kurtosis, this study applies flexible probability density function (pdf) regressions methods that accommodate skewness and kurtosis. This paper concludes that since utility stock returns have a strong response to down markets relative to up markets, there is down market asymmetry in price and returns volatility. This evidence suggests that investors perceive that utility profit regulation is stringent. It also suggests, surprisingly, that the buffering effect has been increased with deregulation. Lastly, robust estimation of financial models performed herein shows that regression estimation should not assume a normally distributed error term.
\end{abstract}

\section{Keywords}

Asymmetric Stock Returns, Electric Utilities, Deregulation, Robust

Estimation, Buffering Effect, Skewed Generalized T Distribution

\section{Introduction}

The electric utility industry, once an industry that supplied a steady stream of 
dividends and slow earnings growth, was the subject of investor and government attention due to continuing crises that commenced soon after deregulation in the late 1990's. During the years after deregulation, California's electricity industry collapsed, and ENRON, the largest bulk electric power marketer, collapsed, and two of the three investor-owned public utilities in California declared bankruptcy. Additionally, $\$ 238$ billion market capitalization was destroyed (Seeholzer [1]), and bond rating down-grades occurred, and a gaping liquidity shortage began to emerge. Roseman and De Martini [2] found that there were 182 utility company bond-rating downgrades and only 15 upgrades. Also, on August 14, 2003, the industry suffered the largest blackout ever that occurred in the Northeastern US, due, in part, to a lack of investment by the industry. The "failure" 1 of regulation leads to reforms toward deregulation that are associated with these events. The industry is partially deregulated as the generation component of the business is unregulated. Additionally, utilities' bulk power lines or transmission lines had been opened to alternative purveyors of electric power. The electric utility industry remains substantially regulated as the rates of return on all but generation assets are regulated throughout the US.

Utility regulatory policy from a shareholder's perspective can be viewed as stringent (unfavorable) or lax (favorable). There is no consensus on the characterization of utility regulatory policy in the literature and among practitioners.

This paper searches for information signals of investors on their perspectives toward regulatory policy in electric utility company stock price volatility soon after the deregulation of the US electric public utility industry. Additionally, utility stock returns responses to up and down markets are modeled for evidence of investor information signals of regulatory behavior. Lax regulation should lead to utility stock returns that react strongly to up markets due to weakly-constrained expected upside profits. Utility stock returns should have a small response to down markets with lax regulation. Lax regulation results in earnings levels that have a strong floor that is independent of systematic risk associated with business and earnings cycles. Stringent regulation should generate a large response of utility stock returns to down markets and a small or no response to up markets for the opposite reasons.

Stock returns data and their error distributions usually have skewness and leptokurtosis, or, thick tails, which is well established in the literature. These characteristics cause intercept bias and inefficiency in slope estimates which is discussed in this paper. Therefore, this study applies skewed generalized t (SGT)

\footnotetext{
${ }^{1}$ Since the mid-1970's rate-base rate-of-return (RB-ROR) regulation was viewed has having encouraged utility managers to over-invest in capital as a way to increase profits as suggested by Averch and Johnson [3]. They claimed that utilities would over-invest to maximize profits (invest beyond the optimal level for cost minimization) if the allowed rate of return is above the cost of capital. Although a number of researchers in the economics of regulation such as Crew and Kleindorfer [4] believe that this article was given too much attention in the literature, it was influential in encouraging the view that utilities over-invest in capital under RB-ROR regulation and that regulation had failed. Today, there are discussions about returning to regulation as it seems to have functioned better than deregulation for the electric utility industry.
} 
probability density function (pdf) regression methods that accommodate skewness and kurtosis. Although there are many flexible pdfs that accommodate skewness and thick tails, the SGT has been found to be the pdf that has the best fitting regressions relative to the normal, other pdfs as well as the flexible pdfs for modeling stock returns.

\section{Literature Review}

Some of the literature suggests, albeit not strongly, that regulatory policy had been lax, as suggested by Binder and Norton [5], Nwaeze [6], and Davidson, Rangan, and Rosenstein [7], Joskow [8] [9].

Some industry observers and utility management have concluded that regulation has been stringent. They point to unattractive financial performance and the resulting lack of investment due to uncertainty regarding regulatory treatment of such assets.

Nwaeze [6] [10] suggest that regulators generally do not reduce electricity prices when an electric utility's actual rate of return on common equity is above the allowed. Joskow [8] [9] also find that utilities do retain profits above the allowed rate of return if electricity rates are not raised. Joskow [8] finds that regulation is relatively lax when factor prices are steady or declining since regulators are not being pressured by customers and utilities. Therefore, the Joskow [8] effect suggests that regulation is stringent when regulators are pressured by customers and utilities, i.e., when the economy is in a recession and stock market prices are depressed.

When general corporate earnings levels are expected to rise, due to an upswing in the business cycle, stock returns rise in such anticipation and an up market occurs. The opposite occurs for down markets. Utility earnings and returns behave in a generally similar manner except that profits may have a strong upside constraint and an associated weak downside constraint, if regulation is stringent. The converse is true with lax regulation. Therefore, one should expect utility stock returns to be relatively more responsive to either down or up markets, depending upon regulatory policy.

Fifty states and the District of Columbia have regulatory jurisdiction of utilities' retail electric business within their boundaries. Therefore, regulatory policy varies across jurisdictions. Additionally, the US Federal Energy Regulatory Commission regulates the returns on utilities' wholesale (transmission) assets. In a study sponsored by the US industry trade association, the Edison Electric Institute, Hirst and Kirby [11] found that transmission investment (long-lines used to transmit bulk, wholesale levels of electric power) fell by $\$ 115$ million annually for 25 years, or $\$ 5$ billion in 1975 to $\$ 2$ billion in 2000 in 1997 dollars.

During down markets, corporate profits are expected to fall. Falling expectations for utility profits may obtain but would be dampened under a lax regulatory or moderate (neither lax nor stringent) regulatory regime as utility profitability has a legally defined guideline found in early 20th century case laws of the 
Hope and Bluefield decisions. ${ }^{2}$ These cases are the standards referred in utility rate cases used for setting allowed rates of returns on common equity. This contrasts with expectations for unconstrained downturns in profits and consequent stock returns for un-regulated firms and markets in general.

This study tests for asymmetry in up and down market utility stock returns as evidence of regulatory policy as perceived by investors soon after deregulation occurred. The change in capital asset market beta (CAPM) associated with the advent of wholesale electric deregulation is estimated and controlled for in the regressions to ascertain how deregulation affected the buffering effect discussed below.

Bawa, Brown, and Klein [12] initially developed the asymmetric response model that was adopted by Pedersen and Satchell [13] for reviewing and testing stock performance measures. That model essentially produces betas for up and down markets, respectively. Asymmetry is captured by differences in up and down market betas. Nwaeze [6] performs a series of regressions of electric utility returns on spreads between actual and allowed rates of return on equity with slope dummies for utility size and regulatory environment. Nwaeze [6] found that stock returns have an asymmetric response to positive and negative abnormal earnings (earnings above or below the allowed rate of return). The empirical results show that positive abnormal earnings have a significant and large positive effect on stock returns and negative abnormal earnings have a significant small negative effect on returns. The notion behind this result is that lax regulation allows for recovery of negative abnormal earnings and utilities retain abnormal positive earnings.

Turning attention to regulation and systematic risk, Peltzman [14] developed the buffering hypothesis that regulation reduces the firm's systematic risk because utility earnings are protected from demand shocks. It also suggests that the cost of capital may be endogenous as the strength of regulation in a particular state jurisdiction affects the systematic risk of the utility.

The buffering hypothesis has been subject to a number of empirical tests. Davidson, Rangan, and Rosenstein [2] estimate the association between systematic risk of electric utilities and regulatory strength. Categorizing the number of electric utilities by regulatory environment, their results show that roughly $75 \%$ of utilities are in jurisdictions that are less binding. They found that regulation affects beta when factor prices, namely, fuel prices, are increasing.

\footnotetext{
${ }^{2}$ The commonly cited landmark US Supreme Court decisions in utility rate cases, Hope Natural Gas and Bluefield Water cases, determined the criteria for a utility's fair rate of return. The Hope decision reaffirmed the standards of reasonableness initially determined in Bluefield. The Hope decision stated "The return to the equity owner should be commensurate with returns on investments in other enterprises having corresponding risks. That return, moreover, should be sufficient to assure confidence in the financial integrity of the enterprise, so as to maintain its credit and attract capital." Utility rates should be set so that the utility has a reasonable opportunity to earn a rate of return equal to its cost of capital, attract capital, maintain its creditworthiness, and that the rate of return should be similar for other investments with similar risk. These cases are the Bluefield Water Works and Improvement Company v. Public Service Commission of West Virginia (1923) and the Federal Power Commission v. Hope Natural Gas Company (1944).
} 
The buffering hypothesis was also tested by Binder and Norton [5]. They concluded that other studies of the buffering hypothesis did not control for other variables that affect risk other than deregulation. They derive an asset beta that is a non-linear function of regulation severity, the Sharp-Lintner core beta (slope in the regression for a demand shock and the returns on the market) and the Ross [15] arbitrage pricing model (APT) core betas (slope coefficients in a regression of demand shocks for a firm on the risk factors common to all security returns). Their empirical results for the electric utility industry support the buffering hypothesis, but their analysis period does not include the mid 1990's early 2000's, the period that involves the fastest movement of the industry toward deregulation.

Binder and Norton [5] find that the decrease in the Sharpe-Lintner core beta indicates that regulators are granting utilities rates of return that are higher than their cost of capital and that the cost of capital or "fair rate of return is a reference to what the lower bound is for the industry.

Nwaeze [10] estimated the impact of the significant electric utility industry reforms adopted over the past 24 years on systematic risk and returns. Using monthly returns for 1976 to 1997, that paper found that deregulation reforms generally reduced the buffering impact and increased systematic risk.

Besanko, Dsouza, and Thiagarajan [16] analyzed electric utility stock price reactions prior to the passing the of the National Energy Policy Act, the legislation that led to the passing of the FERC (Federal Energy Regulatory Commission) Order 888 in April 1996 that commenced wholesale competition and deregulation in the industry. They found that investors had neutral reactions to positive reactions to its passage, yet stock price reactions differed systematically with differences in the utilities' marginal costs.

Turning to robust estimation of models involving stock returns, this study empirically addresses non-normality of stock returns and associated capital asset pricing model (CAPM) regression error distributions. The distributions of stock returns and their regression errors have both leptokurtosis (thick tails relative to the normal pdf) and skewness. The importance of regression methods that accommodate kurtosis and skewness lies in the bias of the intercept and the inefficiency of the estimates and their resulting statistical tests. Chan and Lakonishok [17] test robust estimation methods compared to OLS for estimating beta. Using both simulations (where true values of the parameters of the distribution are known) of returns and actual returns data, they estimate betas with seven robust methods and OLS. They find that substantial efficiency gains are obtained when returns contain extreme outliers such as returns resulting from good or bad news.

The regression methods used to estimate the models herein use flexible probability density functions that accommodate skewness and leptokurtosis to search for the best fit of the data. Robust estimation of CAPM beta is discussed in Butler, McDonald, Nelson, and White [18] and McDonald and Nelson [19]. Theodossiou [20] and Hansen, McDonald, and Theodossiou [21] discuss a number of 
flexible pdf's that can accommodate skewness and kurtosis in the data. These pdfs include the exponential generalized beta of the second kind (EGB2), the skewed generalized error (SGED), skewed generalized T (SGT), and the inverse hyperbolic sine (IHS) distributions. McDonald, Michelfelder, and Theodossiou [22] use these pdf's to estimate and test electric utility betas and find that the SGT provides the best fit. McDonald, Michelfelder, and Theodossiou [23], McDonald and Michelfelder [24] also use these pdf's on stock returns analysis and financial model regressions such as the CAPM. McDonald, Michelfelder, and Theodossiou [23] also performed robust empirical tests of the CAPM parameters of stocks in general and found that Jensen's alpha estimation in the single index model was biased when skewness was present in the regression residuals.

Although this investigation has performed the estimations with all of the above mentioned pdf's along with the symmetric distributions such as the normal, Laplace and the centralized t, the SGT is the pdf chosen for the final estimates, which is highly consistent with much of the aforementioned literature. The SGT estimates are the only set of presented estimates for the sake of brevity. The results of the other pdf's are available upon request.

The estimation method herein applies robust estimation methods that nests the family of symmetric distributions yet are more general and flexible as they accommodate skewness and kurtosis in the pdf returns data and regression residuals.

The remainder of this paper is organized as follows. Section 3 discusses the returns response models. Section 4 reviews the robust probability density functions for estimation. Section 5 presents the data and estimation results. Section 6 is the conclusion.

\section{Returns Response Models}

The model for estimating asymmetric response of utility stock returns to the market is the asymmetric response model initially developed by Bawa, Brown, and Klein [12]. This model nests the one-factor, mean-variance Sharpe-Lintner CAPM. The Pedersen and Satchell [13] asymmetric response model for examining portfolio performance measures is:

$$
R_{i, t}=\alpha_{i}+\beta_{1} R_{m, t}^{-}+\beta_{2} R_{m, t}^{+}+\pi_{i} \delta_{t}+\mu_{i, t}
$$

where $R_{i, t}=r_{i, t}-r_{f, t}$ is excess return for the stock of utility $i$ at period $t, r_{i, t}$ is the total return on the stock of utility $i$ as defined in more detail below, $r_{f, t}$ is the risk free rate for period $t, R_{m, t}=r_{m, t}-r_{f, t}$ is the excess market return, $r_{m, t}$ is the total market return for period $t ; R_{m, t}^{-}=r_{m, t}-r_{f, t}$ When $r_{m, t}-r_{f, t}<0$ and zero otherwise, and $R_{m, t}^{+}=r_{m, t}-r_{f, t}$ when $r_{m, t}-r_{f, t}>0$. And zero otherwise, and $\delta_{t}=$ 1 when $r_{m, t}-r_{f, t}>0$ and zero otherwise,

$$
\pi_{i}=\varphi\left(\beta_{1}-\beta_{2}\right), \varphi=E\left\{r_{m, t}-r_{f, t} \mid r_{m, t}-r_{f, t}>0\right\}
$$

and $\mu_{i, t}$ is an error term.

The asymmetric responses of stock returns to down and up markets are esti- 
mated by tests for difference between $\beta_{1}$ and $\beta_{2}$.

The model for estimating the returns response to the market and deregulation is:

$$
R_{i, t}=\alpha_{i}+\alpha_{n, i} D_{n, t}+\alpha_{r, i} D_{r, t}+\left(\beta_{i}+\beta_{i, n} D_{n, t}+\beta_{i, r} D_{r, t}\right) R_{m, t}+\mu_{i, t}
$$

$R_{m, t}^{-}=R_{m, t}$ for all negative $R_{m, t}$ 's and zero otherwise; $R_{m, t}^{+}=R_{m, t}$ for all non-negative $R_{m, t}$ 's and zero otherwise; $D_{n, t}=1$ for all negative $R_{m, t}$ 's and zero otherwise, and $D_{r, t}=1$ for the post-deregulation period (after April 1996) and zero otherwise. $i_{i, t}$ is the error term. This model is the same as Equation (1) discussed above except for the augmentation of the model to include the slope and intercept post-deregulation dummy variables to estimate the buffering effect (see Appendix 2).

Although reform toward introducing competition to the electric utility industry is a process that started in 1978, this paper identifies the issuance of Order 888 on April 24, 1996 by the Federal Energy Regulatory Commission to be the key event in moving the industry toward competition. The main trend toward deregulation occurred between 1990 and 2002 and therefore is the time frame used for data observation. Next the development of the stock total returns for the utilities is discussed.

The utility total stock return, $r_{i}$, for period $t-1$ to $t$ is

$$
r_{t}=\frac{\Delta P_{t}+D_{t}}{P_{t-1}}=\left(\frac{P_{t}+D_{t}-P_{t-1}}{P_{t-1}}\right)=\left(\frac{P_{t}+D_{t}}{P_{t-1}}\right)-1
$$

where $\Delta P_{t}=P_{t}-P_{t-1}$ is the price change of the share from time $t-1$ to $t$, and $D_{t}$ is the dividend for the period paid at time $t^{3}$ The return can be decomposed into its two components, the capital gain and the dividend yields as follows:

$$
1+r_{t}=\frac{P_{t}+D_{t}}{P_{t-1}}=\left(\frac{P_{t}}{P_{t-1}}\right)\left(\frac{P_{t}+D_{t}}{P_{t}}\right)=\left(1+\frac{\Delta P_{t}}{P_{t}}\right)\left(1+\frac{D_{t}}{P_{t}}\right)=\left(1+k_{t}\right)\left(1+d_{t}\right)
$$

where $k_{t}=\Delta P_{t} / P_{t-1}$ is the capital gain yield or the percent of growth of the stock price from time $t-1$ to $t$ and $d_{t}=D_{t} / P_{t}$ is the percent of dividend with respect to the price at the time of payment.

The log-return or continuously compounded return for the period is defined

$$
\begin{aligned}
l r_{t} & =\ln \left(\frac{P_{t}+D_{t}}{P_{t-1}}\right)=\ln \left(\frac{P_{t}}{P_{t-1}}\right)+\ln \left(\frac{P_{t}+D_{t}}{P_{t}}\right)=\ln \left(1+r_{t}\right) \\
& =\ln \left(1+k_{t}\right)+\ln \left(1+d_{t}\right)=l k_{t}+l d_{t}
\end{aligned}
$$

where $l k_{t}=\ln \left(P_{t} / P_{t-1}\right)=\ln \left(1+k_{t}\right)$ is the log-capital gain yield and $l d_{t}=\ln \left(1+D_{t} / P_{t}\right)=\ln \left(1+d_{t}\right)$ is log-dividend yield for the stock. Note that the

${ }^{3}$ The dividend yield reflects the ex-dividend effect on the share price by lagging the share price by 34 days from the dividend payment date since the ex-dividend period for electric utilities is generally 30 days from the payable date to be a shareholder of record at the utility and the maximum number of days to record a shareholder is 4 days. The ex-dividend period was determined by inspection of footnote B for the company reviews in the electric utility industry analyzed by Value Line Investment Survey [25] in Issues 1, 5, and 11 dated March 8, 2002, April 5, 2002 and May 17, 2002. 
following relationships exist between the return and log-return measures

$$
r_{t}=\mathrm{e}^{l l_{t}}-1, k_{t}=\mathrm{e}^{l k_{t}}-1 \text { and } d_{t}=\mathrm{e}^{l d_{t}}-1 .
$$

The return and log-return for the multi period 0 to $s$, denoted by $\mathrm{r}_{0, s}$ and $l r_{0, s}$ can be computed from the single period returns using the formulas

$$
1+r_{0, s}=\left(1+r_{1}\right)\left(1+r_{2}\right) \cdots\left(1+r_{s}\right)=\prod_{t=1}^{s}\left(1+r_{t}\right)
$$

and

$$
\begin{aligned}
l r_{0, t} & =\ln \left(1+r_{0, s}\right)=\ln \prod_{t=1}^{s}\left(1+r_{t}\right)=\sum_{t=1}^{s} \ln \left(1+r_{t}\right) \\
& =\sum_{t=1}^{s} \ln \left(1+k_{t}\right)+\sum_{t=1}^{s} \ln \left(1+d_{t}\right)=\sum_{t=1}^{s} l k_{t}+\sum_{t=1}^{s} l d_{t}=l k_{0, s}+l d_{0, s}
\end{aligned}
$$

The above formulas assume that the dividend is reinvested each time in the stock of the company immediately after its payment. In such a case, the value of an investment in the stock $s$ periods from now will be

$$
\begin{gathered}
V_{s}=P_{0}\left(1+r_{0, s}\right)=P_{0} \exp \left(\ln \left(1+r_{0, s}\right)\right) \\
P_{0} \exp \left(\sum_{t=1}^{s} l k_{t}+\sum_{t=1}^{s} l d_{t}\right)=P_{0} \exp \left(\sum_{t=1}^{s} l r_{t}\right)
\end{gathered}
$$

Given a sequence, $V_{0}=P_{0}, V_{1}, V_{2}, \cdots, V_{s}, \cdots$, the return and log-return for each period can be computed easily from them using the equations

$$
r_{t}=\frac{V_{t}}{V_{t-1}}-1 \text { and } l r_{t}=\ln \left(\frac{V_{t}}{V_{t-1}}\right)
$$

\section{Flexible Probability Density Functions for Estimation and Robustness Checks}

The flexible pdf's used for the estimations accommodate skewness and kurtosis. Although not presented in this paper, the normal, centralized $t$, Laplace, and the flexible pdf's, exponential beta of the second kind, (EGB2), skewed generalized error distribution (SGED), skewed generalized $t$ (SGT) and the inverse hyperbolic sine (IHS) were used for the regression estimations for comparison and robustness checks. The normal pdf is not appropriate when the error term exhibits a distribution with skewness or thick tails and no symmetric pdf is appropriate when skewness is present in the data or error term. The shape of the normal pdf is completely described by the first and second moments, namely mean and variance. Pdf's that accommodate flexible values for the third and fourth moments, skewness and kurtosis offer efficient estimates for financial models relative to OLS where skewness or kurtosis is present. Harvey and Siddique [26], [27] estimate skewness in different industry stock portfolios and market portfolio indices and find substantial evidence of skewness in returns. Theodossiou [20] rejected the assumption of normality, based on tests of skewness and kurtosis for multiple stock exchanges indexes, the Canadian- and Japanese-Dollar exchange rates and the price of gold. Since skewness and kurtosis is found frequently in 
financial returns, the approach used herein was to consider pdf's that would appropriately model the asymmetries and thick tails characteristics found in returns data.

Hein and Westfall [28] found that performing event studies with multivariate regressions using traditional dummy variable tests, assuming that the distribution of the error term is normal, can be biased and inefficient and lead to wrong inferences as stock returns are found to be typically non-normally distributed. This paper uses multivariate regressions with event dummies but considered the multitude of pdf's that accommodate skewness and kurtosis. The chosen flexible pdf is the SGT.

A description of the SGT pdf as well as the other flexible pdf's considered for the final estimations are found in Hansen, McDonald, and Theodossiou [21] and McDonald, Michelfelder, and Theodossiou [23]. The SGT is presented below as the pdf of choice. ${ }^{4}$

\section{Skewed Generalized T Probability Density Function}

The SGT pdf is specified as:

$$
S G T(y ; \mu, \sigma, n, k, \lambda)=\frac{C}{\sigma}\left(1+\frac{1}{((n-2) / k)(1+\operatorname{sign}(\varepsilon) \lambda)^{k} \theta^{k} \sigma^{k}}|\varepsilon|^{k}\right)^{-(n+1) / k}
$$

where

$$
\begin{gathered}
C=k /\left((2(n-2) / k)^{1 / k} \theta B(1 / k, n / k)\right), \\
\theta=(k /(n-2))^{1 / k} B(1 / k, n / k)^{0.5} B(3 / k,(n-2) / k)^{0.5} S(\lambda)^{-1}, \\
S(\lambda)=\sqrt{1+3(\lambda)^{2}-4 A^{2} \lambda^{2}}, \\
A=B((2 / k,(n-1) / k)) B(1 / k, n / k)^{-0.5} B(3 / k,(n-2) / k)^{0.5}, \\
\delta=2 \lambda A S(\lambda)^{-1},
\end{gathered}
$$

$B()$ is the beta function, $\mu$ and $\sigma$ are the mean and standard deviation of $y, n$ and $k$ are kurtosis parameters, $\lambda$ is a skewness parameter obeying the constraint

${ }^{4}$ The exponential generalized beta of the second kind, the skewed generalized error, inverse hyperbolic sine pdf's that also accommodate skewness and kurtosis were also estimated as well as the centralized T, Laplace and normal pdf's were also used for the regressions estimations. Since log-likelihood ratio tests cannot be performed for pdf's with non-nested pdfs. The choice of final pdf for estimation results is based on the highest log-likelihood function. The likelihood ratio test among flexible pdf's and the normal are all statistically significant at the $99 \%$ level. The LR-Normal is a log-likelihood ratio statistic for testing the normal pdf against the other pdf's for best fit as long as the alternative pdf nests the normal. It is computed as LR-Normal $=2\left(I_{a}-I_{n}\right)$ where $l a$ and $I n$ are the log-likelihood functions for the alternative and normal pdf's respectfully. The LR-Normal is asymptotically distributed as $\chi^{2}$ with $k$ degrees of freedom where $k$ is the number of additional parameters for each pdf. For the centralized t, $k=1$ and for the SGED, EGB2, and IHS, $k=2$ and for the SGT, $k=3$. The SGT pdf had the highest log-likelihood for all of the* pdf's and is chosen as the pdf of choice for the estimations in this paper. Table 3 includes the LR-Normal test for the SGT and the normal pdfs. The LR-Normal for the SGT is statistically significant at the $99 \%$ level for every utility estimation. 
$|\lambda|<1, \operatorname{sign}$ is the sign function, and $\mu=y-\mu+\delta \sigma$ is the deviation of $y$ from its mode $\mu-\delta \sigma$. Positive values of $\lambda$ result a positively skewed pdf and vice versa. Note that the parameter $\delta$ is the skewness measure $S K=(\mu-\operatorname{mode}(y)) / \sigma$. For $\lambda$ $=0$ the SGT yields the GT of McDonald and Newey [29]. Letting $n$ grow indefinitely large gives the SGED and the GED for $\lambda=0$. Standardized values for skewness and kurtosis in the ranges $(-\infty, \infty)$ and $(1.8, \infty)$ can be modeled with the SGT.

The asymmetric response models were estimated using maximum likelihood estimation.

\section{Estimation}

\subsection{The Data}

The sample includes all electric and electric and gas combination companies listed in Compust at database as of September 26, 1996 that were publicly traded between January 1, 1990 and July 31, 2002. These include all publicly-traded companies with SIC codes 4911 and 4931.

Opening, high, low, and close daily stock prices were obtained for the period beginning the first trading day in January 1990 and ending on December July 31, 2002 from www.msn.com. The time frame of data observation from 1990 to 2002 was purposely used as that was the transition period from regulation to deregulation in the generation portion of the US electric utility industry. Utility company paid dividends were obtained from www.msn.com. There are 3026 daily total return observations for each utility and the S \& P 500 total returns index. Value Line Investment Survey [25] Issues 1, 5, and 11 dated March 8, April 5, and May 17, 2002 lists 63 publicly traded electric/electric and gas combination companies. The sample frame includes 36 electric utilities that have been continuously traded during the defined period. Appendix 1 ncludes a list of all utilities included in the sample. El Paso Electric was removed from the sample frame since that company had severe financial problems during the 1990's including bankruptcy. Trading volume was extremely low during periods in the 1990's and the stock traded at values less than $\$ 1$ for a number of months.

The sample frame period had been an era of mergers and acquisitions as electric utilities consolidated as a response to growing competition and deregulation in the generation portion of the electric utility industry. During the mid 1980's there were roughly 110 publicly traded electric and electric and gas combination utilities and as of the $2^{\text {nd }}$ quarter of 2002 there were 63 , approaching 50 percent industry consolidation in the number of traded utilities.

Market and utility returns are daily total stock returns. The market is defined by the S \& P 500. The total returns index for the S \& P 500 was obtained from http://www.globalfinancialdata.com/. Utility stock total returns were calculated as described above. Total returns (rather than price changes only) were used for all analysis since utilities' dividend yields are relatively high and dividend payments consistent, therefore dividends are a substantial component of investor 
returns. The inclusion of dividends is also important since dividend yields dampen reductions in total returns when stock prices decline. As the stock price falls, the dividend yield rises. The risk-free rate is the daily 30-day yield on 90 day US Treasury Bills obtained from Global Financial Data, Inc.'s web site, www.globalfinancialdata.com.

Table 1 has the mean, standard deviation, skewness, and kurtosis for the daily S \& P 500 total returns and each utility for the study period January 1990-July 2002. The mean total return for the S \& P 500 for the period is similar to the mean return of all the utilities ( 0.042 and 0.041 respectively). The standard deviation for both the S \& P 500 and the utilities are roughly 25 to 40 fold higher than the mean returns. The skewness for the S \& P 500 is negative $(-0.038)$, it is positive for 34 of the 36 utilities' total returns and the mean skewness for all of the utilities is positive (0.099).

Consistently positive and large skewness for utilities compared to the S \& $\mathrm{P}$ 500 indicates that utilities' total returns have a higher probability of being large and positive compared to the $\mathrm{S} \& \mathrm{P} 500$. Kurtosis is similar for utilities with a utility mean of 11.21 (median is 7.74) compared to the S \& P 500 kurtosis of 7.93. Kurtosis for the normal pdf is 3. The kurtosis of the utilities and the S \& P 500 provide evidence that the pdf's of their returns are leptokurtic.

As an initial test of the normality of the regression residuals, the standard econometric version of the CAPM was estimated (with excess returns) using the flexible pdf's, the centralized $\mathrm{T}$, and Laplace with maximum likelihood, and the normal pdf using OLS. Although it is beyond the scope of this paper to present and discuss many of the inter-pdf characteristics of the results, the SGT pdf was chosen as the main choice of estimation among the flexible pdf's as discussed in footnote 5 . The SGT nests the normal pdf as a special case therefore comparison and testing of the SGT against the normal can be done with a chi-squared distributed likelihood ratio test. The model estimations are discussed in the next subsection.

\subsection{Model Estimations}

Table 2, pages 1 - 3 displays SGT estimates of the econometric CAPM for the entire sample period. All of the beta estimates are significant except for two utilities. The $\chi^{2}$ distributed likelihood ratio test (LR-Normal) for comparing the fit of the normal and the SGT pdf's is statistically significant for every utility estimate, indicating that the SGT regressions provide a better fit of the data. The skewness $(S K)$ and kurtosis $(K U)$ parameters for the CAPM regression error terms indicates that the distribution of the returns residuals is non-normal. Skewness is not defined for the SGT pdf for all pdf parameter ranges (at $n<3$ ) therefore a few utilities do not have an estimate for skewness. Although most of the estimates of the skewness parameter are positive, they are generally quite small. The skewness parameter estimates of the SGT, $\lambda$, are positive, only three of them are statistically significant. 
Table 1. First through fourth moments summary statistics of utility and S \& P 500 Returns: 1990-2002.

\begin{tabular}{|c|c|c|c|c|}
\hline & $\mu$ & $\sigma$ & Skewness & Kurtosis \\
\hline S \& P 500 & 0.04214 & 1.02090 & -0.03802 & 7.93318 \\
\hline AEP & 0.03092 & 1.28463 & 0.08322 & 7.43292 \\
\hline CIN & 0.04791 & 1.28907 & 0.11355 & 6.55949 \\
\hline CMS & 0.00373 & 1.72070 & 0.06856 & \\
\hline $\mathrm{D}$ & 0.05308 & 1.17777 & 0.06159 & 9.73302 \\
\hline DPL & 0.06195 & 1.37598 & 0.14146 & 6.66801 \\
\hline DTE & 0.05000 & 1.26403 & 0.10753 & 5.91875 \\
\hline DUK & 0.05085 & 1.44103 & 0.12134 & 7.29301 \\
\hline $\mathrm{ED}$ & 0.04741 & 1.30253 & -0.04474 & 5.97970 \\
\hline EDE & 0.04039 & 1.24469 & 0.12190 & 7.97978 \\
\hline EIX & 0.01303 & 1.75458 & 0.04157 & 14.51847 \\
\hline ETR & 0.06013 & 1.45669 & 0.23370 & 17.75511 \\
\hline FPL & 0.05005 & 1.26054 & 0.01300 & \\
\hline GMP & 0.00989 & 1.38778 & 0.03994 & 14.18595 \\
\hline $\mathrm{HE}$ & 0.03362 & 1.06177 & 0.10635 & 7.19879 \\
\hline IDA & 0.02748 & 1.27363 & 0.08635 & 8.98244 \\
\hline NI & 0.05315 & 1.31132 & 0.14622 & 7.72411 \\
\hline $\mathrm{NU}$ & 0.03773 & 1.48852 & 0.09106 & 7.61698 \\
\hline OGE & 0.06398 & 1.32225 & 0.18221 & 8.15353 \\
\hline PCG & 0.00727 & 1.69361 & 0.02540 & 15.45331 \\
\hline PEG & 0.04365 & 1.33727 & -0.17516 & 34.07430 \\
\hline PGN & 0.03804 & 1.25055 & 0.15202 & 48.75561 \\
\hline PNM & 0.02811 & 1.76315 & 0.05144 & 6.73357 \\
\hline PNW & 0.05630 & 1.56488 & 0.14052 & 8.96838 \\
\hline POM & 0.02646 & 1.33289 & 0.07297 & 7.76233 \\
\hline PPL & 0.04909 & 1.44138 & 0.13619 & 8.84195 \\
\hline PSD & 0.03719 & 1.22748 & 0.10130 & 7.09781 \\
\hline SCG & 0.04488 & 1.12971 & 0.14018 & 7.51896 \\
\hline SO & 0.06908 & 1.37276 & 0.18143 & 18.41280 \\
\hline SRP & 0.06473 & 1.52926 & 0.25138 & 14.18762 \\
\hline $\mathrm{TE}$ & 0.04298 & 1.22600 & 0.11201 & 6.87562 \\
\hline TXU & 0.05537 & 1.30845 & 0.20068 & 18.78902 \\
\hline UIL & 0.04499 & 1.10982 & 0.11882 & 6.25387 \\
\hline UTL & 0.03428 & 1.46703 & 0.08213 & 7.35301 \\
\hline WEC & 0.03727 & 1.18433 & 0.08613 & 5.89381 \\
\hline WPS & 0.04212 & 1.05327 & 0.11306 & 6.02368 \\
\hline WR & 0.02219 & 1.34276 & 0.06690 & 8.66620 \\
\hline Util. Mean & 0.041092 & 1.354225 & 0.099228 & 11.21663 \\
\hline Util. Median & 0.043315 & 1.316785 & 0.106940 & 7.74322 \\
\hline
\end{tabular}


Table 2. SGT estimates of the CAPM BETA for the period 1990-2002.

\begin{tabular}{|c|c|c|c|c|c|c|c|c|c|c|c|c|}
\hline Data & AEP & CIN & CMS & $\mathrm{D}$ & DPL & DTE & DUK & ED & EDE & EIX & ETR & FPL \\
\hline$\alpha$ & $\begin{array}{c}0.01264 \\
(0.58)\end{array}$ & $\begin{array}{c}0.03244 \\
(1.46)\end{array}$ & $\begin{array}{c}-0.00834 \\
(-0.29)\end{array}$ & $\begin{array}{c}0.04115 \\
(2.03)^{*}\end{array}$ & $\begin{array}{c}0.05275 \\
(2.22)^{*}\end{array}$ & $\begin{array}{c}0.03828 \\
(1.77)\end{array}$ & $\begin{array}{c}0.03128 \\
(1.26)\end{array}$ & $\begin{array}{c}0.03012 \\
(1.35)\end{array}$ & $\begin{array}{c}0.03244 \\
(1.49)\end{array}$ & $\begin{array}{c}0.00473 \\
(0.15)\end{array}$ & $\begin{array}{c}0.04626 \\
(1.82)\end{array}$ & $\begin{array}{c}0.03469 \\
(1.62)\end{array}$ \\
\hline$\beta$ & $\begin{array}{c}0.37872 \\
(22.89)^{* *}\end{array}$ & $\begin{array}{c}0.36077 \\
(21.43)^{\star *}\end{array}$ & $\begin{array}{c}0.28526 \\
(13.94)^{* *}\end{array}$ & $\begin{array}{l}0.35567 \\
(23.7)^{\star \star}\end{array}$ & $\begin{array}{c}0.33977 \\
(18.13)^{* *}\end{array}$ & $\begin{array}{c}0.41714 \\
(24.75)^{\star *}\end{array}$ & $\begin{array}{c}0.42805 \\
(23.91)^{\star *}\end{array}$ & $\begin{array}{l}0.41623 \\
(22.8)^{\star *}\end{array}$ & $\begin{array}{l}0.15795 \\
(9.83)^{\star \star}\end{array}$ & $\begin{array}{c}0.47156 \\
(22.42)^{\star *}\end{array}$ & $\begin{array}{c}0.31852 \\
(15.98)^{\star *}\end{array}$ & $\begin{array}{c}0.33321 \\
(20.78)^{* *}\end{array}$ \\
\hline$\hat{\sigma}$ & $\begin{array}{c}1.23089 \\
(36.98)^{\star \star}\end{array}$ & $\begin{array}{c}1.22791 \\
(44.86)^{\star *}\end{array}$ & $\begin{array}{c}1.7489 \\
(16.4)^{\star *}\end{array}$ & $\begin{array}{c}1.15796 \\
(25.33)^{\star *}\end{array}$ & $\begin{array}{c}1.32319 \\
(39.91)^{\star *}\end{array}$ & $\begin{array}{c}1.20056 \\
(39.89)^{\star *}\end{array}$ & $\begin{array}{c}1.37718 \\
(40.83)^{\star *}\end{array}$ & $\begin{array}{c}1.24393 \\
(43.33)^{* *}\end{array}$ & $\begin{array}{c}1.2053 \\
(43.98)^{\star *}\end{array}$ & $\begin{array}{l}2.52876 \\
(5.28)^{\star \star}\end{array}$ & $\begin{array}{c}1.43755 \\
(35.53)^{\star *}\end{array}$ & $\begin{array}{l}1.22625 \\
(26.4)^{* *}\end{array}$ \\
\hline$K$ & $\begin{array}{c}1.57664 \\
(11.89)^{\star *}\end{array}$ & $\begin{array}{c}1.3988 \\
(10.66)^{\star *}\end{array}$ & $\begin{array}{c}2.13438 \\
(11.04)^{\star *}\end{array}$ & $\begin{array}{c}1.73995 \\
(10.61)^{\star *}\end{array}$ & $\begin{array}{c}1.86872 \\
(12.29)^{\star *}\end{array}$ & $\begin{array}{l}1.80353 \\
(11.3)^{\star \star}\end{array}$ & $\begin{array}{c}1.35557 \\
(12.36)^{\star *}\end{array}$ & $\begin{array}{l}1.94618 \\
(9.78)^{\star *}\end{array}$ & $\begin{array}{c}1.38038 \\
(16.15)^{\star *}\end{array}$ & $\begin{array}{c}2.09635 \\
(11)^{\star *}\end{array}$ & $\begin{array}{c}1.92125 \\
(11.75)^{\star *}\end{array}$ & $\begin{array}{c}1.9214 \\
(10.78)^{\star \star}\end{array}$ \\
\hline$\lambda$ & $\begin{array}{c}0.01993 \\
(0.88)\end{array}$ & $\begin{array}{c}0.02316 \\
(1.08)\end{array}$ & $\begin{array}{c}0.01796 \\
(0.7)\end{array}$ & $\begin{array}{c}0.01808 \\
(0.78)\end{array}$ & $\begin{array}{c}0.05783 \\
(2.34)^{*}\end{array}$ & $\begin{array}{c}0.0368 \\
(1.52)\end{array}$ & $\begin{array}{c}0.00742 \\
(0.35)\end{array}$ & $\begin{array}{c}0.00132 \\
(0.05)\end{array}$ & $\begin{array}{l}0.0375 \\
(1.71)\end{array}$ & $\begin{array}{c}-0.00666 \\
(-0.27)\end{array}$ & $\begin{array}{c}0.04697 \\
(1.9)\end{array}$ & $\begin{array}{c}0.00514 \\
(0.21)\end{array}$ \\
\hline$n$ & $\begin{array}{c}4.7153 \\
(6.06)^{\star \star}\end{array}$ & $\begin{array}{l}8.14022 \\
(2.68)^{\star *}\end{array}$ & $\begin{array}{c}2.83973 \\
(11.66)^{\star *}\end{array}$ & $\begin{array}{c}3.8967 \\
(6.11)^{\star \star}\end{array}$ & $\begin{array}{l}4.46409 \\
(7.78)^{\star \star}\end{array}$ & $\begin{array}{c}4.8989 \\
(5.85)^{\star \star}\end{array}$ & $\begin{array}{c}6.1737 \\
(4.48)^{\star \star}\end{array}$ & $\begin{array}{c}5.4031 \\
(4.51)^{\star \star}\end{array}$ & $\begin{array}{l}5.91206 \\
(7.83)^{\star *}\end{array}$ & $\begin{array}{c}2.31309 \\
(13.38)^{\star *}\end{array}$ & $\begin{array}{l}4.04235 \\
(8.17)^{\star *}\end{array}$ & $\begin{array}{l}3.65427 \\
(7.51)^{* *}\end{array}$ \\
\hline$S K$ & 0.12846 & 0.10119 & $\mathrm{n} / \mathrm{a}$ & 0.16105 & 0.33563 & 0.189 & 0.04159 & 0.0054 & 0.21373 & $\mathrm{n} / \mathrm{a}$ & 0.33541 & 0.05259 \\
\hline$K U$ & 16.74093 & 6.87491 & $\mathrm{n} / \mathrm{a}$ & $\mathrm{n} / \mathrm{a}$ & 18.00594 & 11.2943 & 10.03874 & 7.53358 & 10.57564 & $\mathrm{n} / \mathrm{a}$ & 157.40163 & $\mathrm{n} / \mathrm{a}$ \\
\hline $\log \mathrm{L}$ & -4631.58 & -4731.1 & -5321.66 & -4384.13 & -4915.63 & -4650.79 & -4982.82 & -4827.62 & -4574.69 & -5524.25 & -5122.28 & -4562.86 \\
\hline LR-N. & $626.77^{\star \star}$ & $356.77^{\star *}$ & $1376.83^{\star *}$ & $570.44^{* *}$ & $555.16^{* *}$ & $387.37^{* *}$ & $603.04^{* *}$ & $219.9^{\star *}$ & $1064.3^{* *}$ & $2342.45^{\star *}$ & $617.93^{* *}$ & $625.12^{\star *}$ \\
\hline $\mathrm{R} 2$ & 0.08796 & 0.08452 & 0.02661 & 0.09582 & 0.06226 & 0.11384 & 0.09067 & 0.10726 & 0.01501 & 0.04539 & 0.04814 & 0.07417 \\
\hline OBS & 3026 & 3026 & 3026 & 3026 & 3026 & 3026 & 3026 & 3026 & 3026 & 3026 & 3026 & 3026 \\
\hline Data & GMP & $\mathrm{HE}$ & IDA & NI & NU & OGE & PCG & PEG & PGN & PNM & PNW & POM \\
\hline$\alpha$ & $\begin{array}{c}0.01708 \\
(0.63)\end{array}$ & $\begin{array}{c}0.02526 \\
(1.38)\end{array}$ & $\begin{array}{c}0.01703 \\
(0.77)\end{array}$ & $\begin{array}{c}0.04233 \\
(1.86)\end{array}$ & $\begin{array}{c}0.02871 \\
(1.1)\end{array}$ & $\begin{array}{c}0.05375 \\
(2.35)^{*}\end{array}$ & $\begin{array}{c}0.02504 \\
(0.78)\end{array}$ & $\begin{array}{c}0.02812 \\
(1.24)\end{array}$ & $\begin{array}{c}0.01937 \\
(0.92)\end{array}$ & $\begin{array}{c}0.01434 \\
(0.48)\end{array}$ & $\begin{array}{c}0.04156 \\
(1.54)\end{array}$ & $\begin{array}{c}0.01162 \\
(0.49)\end{array}$ \\
\hline$\beta$ & $\begin{array}{c}0 \\
(0)\end{array}$ & $\begin{array}{l}0.25115 \\
(17.8)^{\star *}\end{array}$ & $\begin{array}{c}0.28275 \\
(17.02)^{\star *}\end{array}$ & $\begin{array}{c}0.2745 \\
(16.28)^{\star *}\end{array}$ & $\begin{array}{c}0.26276 \\
(13.39)^{\star *}\end{array}$ & $\begin{array}{c}0.26909 \\
(15.83)^{\star *}\end{array}$ & $\begin{array}{c}0.45387 \\
(23.01)^{\star *}\end{array}$ & $\begin{array}{c}0.39926 \\
(22.84)^{\star *}\end{array}$ & $\begin{array}{c}0.40404 \\
(24.81)^{\star *}\end{array}$ & $\begin{array}{c}0.36322 \\
(15.33)^{\star *}\end{array}$ & $\begin{array}{c}0.28999 \\
(14.04)^{\star *}\end{array}$ & $\begin{array}{c}0.33895 \\
(18.49)^{\star *}\end{array}$ \\
\hline$\hat{\sigma}$ & $\begin{array}{c}1.51031 \\
(37.36)^{\star *}\end{array}$ & $\begin{array}{c}1.03229 \\
(31.91)^{\star *}\end{array}$ & $\begin{array}{c}1.28364 \\
(24.93)^{\star *}\end{array}$ & $\begin{array}{c}1.27692 \\
(36.04)^{\star *}\end{array}$ & $\begin{array}{c}1.48315 \\
(29.76)^{\star *}\end{array}$ & $\begin{array}{c}1.29844 \\
(32.69)^{\star *}\end{array}$ & $\begin{array}{c}3.70063 \\
(33.23)^{\star *}\end{array}$ & $\begin{array}{c}1.27678 \\
(33.74)^{\star *}\end{array}$ & $\begin{array}{c}1.19715 \\
(40.24)^{\star *}\end{array}$ & $\begin{array}{l}1.70006 \\
(40.4)^{\star *}\end{array}$ & $\begin{array}{c}1.54067 \\
(35.22)^{\star *}\end{array}$ & $\begin{array}{l}1.32433 \\
(34.1)^{* *}\end{array}$ \\
\hline$K$ & $\begin{array}{c}0.89041 \\
(12.15)^{\star *}\end{array}$ & $\begin{array}{c}1.7801 \\
(10.69)^{* *}\end{array}$ & $\begin{array}{c}1.89576 \\
(11.65)^{\star *}\end{array}$ & $\begin{array}{c}1.61926 \\
(12.38)^{\star *}\end{array}$ & $\begin{array}{c}1.7651 \\
(11.54)^{\star *}\end{array}$ & $\begin{array}{c}1.64702 \\
(12.09)^{\star *}\end{array}$ & $\begin{array}{c}2.59563 \\
(14.12)^{\star *}\end{array}$ & $\begin{array}{c}1.72383 \\
(10.76)^{\star \star}\end{array}$ & $\begin{array}{c}1.86959 \\
(16.81)^{\star *}\end{array}$ & $\begin{array}{c}2.20637 \\
(11.67)^{\star *}\end{array}$ & $\begin{array}{c}1.91113 \\
(12.84)^{\star *}\end{array}$ & $\begin{array}{c}1.72963 \\
(10.93)^{* *}\end{array}$ \\
\hline$\lambda$ & $\begin{array}{c}0.00893 \\
(0.53)\end{array}$ & $\begin{array}{c}0.01915 \\
(0.81)\end{array}$ & $\begin{array}{c}0.00958 \\
(0.4)\end{array}$ & $\begin{array}{c}0.03129 \\
(1.37)\end{array}$ & $\begin{array}{c}0.03459 \\
(1.47)\end{array}$ & $\begin{array}{l}0.04544 \\
(1.98)^{\star}\end{array}$ & $\begin{array}{c}0.02206 \\
(0.85)\end{array}$ & $\begin{array}{c}-0.01319 \\
(-0.57)\end{array}$ & $\begin{array}{c}0.03266 \\
(1.31)\end{array}$ & $\begin{array}{l}0.06899 \\
(2.62)^{\star *}\end{array}$ & $\begin{array}{c}0.02404 \\
(0.98)\end{array}$ & $\begin{array}{c}0.02423 \\
(1.03)\end{array}$ \\
\hline$n$ & $\begin{array}{l}8.47444 \\
(3.16)^{\star \star}\end{array}$ & $\begin{array}{l}4.29366 \\
(5.9)^{\star *}\end{array}$ & $\begin{array}{l}3.40655 \\
(9.16)^{\star \star}\end{array}$ & $\begin{array}{l}4.45892 \\
(6.83)^{\star \star}\end{array}$ & $\begin{array}{c}3.9108 \\
(7.18)^{\star *}\end{array}$ & $\begin{array}{l}4.14196 \\
(7.16)^{\star \star}\end{array}$ & $\mathrm{n} / \mathrm{a}$ & $\begin{array}{c}4.5781 \\
(5.38)^{\star \star}\end{array}$ & $\begin{array}{c}3.82797 \\
(20.82)^{\star *}\end{array}$ & $\begin{array}{l}4.09302 \\
(9.09)^{\star *}\end{array}$ & $\begin{array}{c}3.80983 \\
(10.07)^{\star *}\end{array}$ & $\begin{array}{l}4.43101 \\
(5.87)^{\star \star}\end{array}$ \\
\hline$S K$ & 0.07244 & 0.1281 & 0.14737 & 0.21603 & 0.29957 & 0.36192 & $\mathrm{n} / \mathrm{a}$ & -0.08038 & 0.28550 & 0.41152 & 0.20891 & 0.15657 \\
\hline$K U$ & 15.25315 & 28.4597 & $\mathrm{n} / \mathrm{a}$ & 23.03044 & $\mathrm{n} / \mathrm{a}$ & 65.12891 & $\mathrm{n} / \mathrm{a}$ & 16.91787 & $\mathrm{n} / \mathrm{a}$ & 60.11703 & $\mathrm{n} / \mathrm{a}$ & 21.4893 \\
\hline $\log \mathrm{L}$ & -4800.23 & -4120.4 & -4617.66 & -4727.17 & -5144.01 & -4738.13 & -5421.32 & -4782.28 & -4512.1 & -5696.39 & -5286.74 & -4876.01 \\
\hline LR-N. & $1763.69^{* *}$ & $468.92^{\star *}$ & $938.52^{\star *}$ & $710.16^{\star *}$ & $665.23^{\star *}$ & $766.09^{* *}$ & $2532.76^{\star *}$ & $449.98^{* *}$ & $18181.1^{\star \star}$ & $519.5^{\star *}$ & $1046.42^{\star *}$ & $503.67^{* *}$ \\
\hline $\mathrm{R} 2$ & 0 & 0.05861 & 0.04686 & 0.04484 & 0.03197 & 0.04206 & 0.04261 & 0.09575 & 0.00037 & 0.04413 & 0.03124 & 0.06583 \\
\hline OBS & 3026 & 3026 & 3026 & 3026 & 3026 & 3026 & 3026 & 3026 & 3026 & 3026 & 3026 & 3026 \\
\hline
\end{tabular}




\begin{tabular}{|c|c|c|c|c|c|c|c|c|c|c|c|c|}
\hline Data & PPL & PSD & SCG & SO & SRP & $\mathrm{TE}$ & TXU & UIL & UTL & WEC & WPS & WR \\
\hline$\alpha$ & $\begin{array}{c}0.03794 \\
(1.51)\end{array}$ & $\begin{array}{l}0.0281 \\
(1.32)\end{array}$ & $\begin{array}{c}0.03463 \\
(1.75)\end{array}$ & $\begin{array}{c}0.05432 \\
(2.3)^{\star}\end{array}$ & $\begin{array}{c}0.01638 \\
(0.58)\end{array}$ & $\begin{array}{c}0.03161 \\
(1.48)\end{array}$ & $\begin{array}{c}0.04145 \\
(1.83)\end{array}$ & $\begin{array}{c}0.03472 \\
(1.81)\end{array}$ & $\begin{array}{c}0.03334 \\
(1.07)\end{array}$ & $\begin{array}{c}0.02829 \\
(1.36)\end{array}$ & $\begin{array}{c}0.03052 \\
(1.69)\end{array}$ & $\begin{array}{c}0.00937 \\
(0.39)\end{array}$ \\
\hline$\beta$ & $\begin{array}{l}0.32879 \\
(18.5)^{\star *}\end{array}$ & $\begin{array}{c}0.26917 \\
(16.52)^{\star *}\end{array}$ & $\begin{array}{c}0.27145 \\
(19.03)^{\star *}\end{array}$ & $\begin{array}{c}0.38496 \\
(20.61)^{\star *}\end{array}$ & $\begin{array}{c}0.27807 \\
(15.09)^{\star *}\end{array}$ & $\begin{array}{c}0.26518 \\
(16.21)^{\star *}\end{array}$ & $\begin{array}{c}0.3327 \\
(18.89)^{\star *}\end{array}$ & $\begin{array}{c}0.25387 \\
(16.27)^{\star *}\end{array}$ & $\begin{array}{c}0 \\
(0)\end{array}$ & $\begin{array}{c}0.29023 \\
(17.65)^{\star *}\end{array}$ & $\begin{array}{c}0.27091 \\
(18.88)^{\star *}\end{array}$ & $\begin{array}{c}0.25373 \\
(14.76)^{\star *}\end{array}$ \\
\hline$\hat{\sigma}$ & $\begin{array}{l}1.44237 \\
(25.6)^{* *}\end{array}$ & $\begin{array}{c}1.1919 \\
(36.73)^{\star *}\end{array}$ & $\begin{array}{c}1.10238 \\
(33.34)^{\star *}\end{array}$ & $\begin{array}{c}1.34322 \\
(41.04)^{* *}\end{array}$ & $\begin{array}{l}1.90986 \\
(8.62)^{\star *}\end{array}$ & $\begin{array}{c}1.17319 \\
(43.16)^{\star *}\end{array}$ & $\begin{array}{c}1.28233 \\
(27.04)^{* *}\end{array}$ & $\begin{array}{c}1.06128 \\
(49.29)^{\star *}\end{array}$ & $\begin{array}{c}1.50574 \\
(32.71)^{\star *}\end{array}$ & $\begin{array}{c}1.15014 \\
(38.41)^{* *}\end{array}$ & $\begin{array}{c}0.99239 \\
(52.91)^{* *}\end{array}$ & $\begin{array}{c}1.4101 \\
(22.38)^{* *}\end{array}$ \\
\hline$K$ & $\begin{array}{c}1.57153 \\
(11.37)^{\star \star}\end{array}$ & $\begin{array}{c}1.68135 \\
(11.47)^{\star *}\end{array}$ & $\begin{array}{c}1.40588 \\
(10.74)^{\star *}\end{array}$ & $\begin{array}{c}2.0868 \\
(13.57)^{\star *}\end{array}$ & $\begin{array}{c}1.96469 \\
(11.25)^{* *}\end{array}$ & $\begin{array}{c}1.39883 \\
(10.76)^{* *}\end{array}$ & $\begin{array}{c}2.03412 \\
(10.23)^{\star *}\end{array}$ & $\begin{array}{c}1.67291 \\
(13.42)^{\star *}\end{array}$ & $\begin{array}{c}0.99411 \\
(12.11)^{* *}\end{array}$ & $\begin{array}{c}1.88553 \\
(10.62)^{\star *}\end{array}$ & $\begin{array}{l}1.55622 \\
(12.9)^{\star \star}\end{array}$ & $\begin{array}{l}1.65203 \\
(11.1)^{* *}\end{array}$ \\
\hline$\lambda$ & $\begin{array}{c}0.04057 \\
(1.83)\end{array}$ & $\begin{array}{c}-0.00542 \\
(-0.23)\end{array}$ & $\begin{array}{c}0.02084 \\
(0.98)\end{array}$ & $\begin{array}{c}0.04126 \\
(1.6)\end{array}$ & $\begin{array}{c}0.01396 \\
(0.58)\end{array}$ & $\begin{array}{c}0.02309 \\
(1.07)\end{array}$ & $\begin{array}{c}0.02145 \\
(0.85)\end{array}$ & $\begin{array}{c}-0.00447 \\
(-0.19)\end{array}$ & $\begin{array}{c}0.01642 \\
(0.73)\end{array}$ & $\begin{array}{l}0.05015 \\
(2.02)^{*}\end{array}$ & $\begin{array}{c}0.04414 \\
(1.93)\end{array}$ & $\begin{array}{c}0.00421 \\
(0.19)\end{array}$ \\
\hline$n$ & $\begin{array}{c}3.95257 \\
(6.2)^{\star \star}\end{array}$ & $\begin{array}{l}4.67901 \\
(5.89)^{\star *}\end{array}$ & $\begin{array}{l}5.41577 \\
(3.91)^{\star \star}\end{array}$ & $\begin{array}{c}3.97617 \\
(12.14)^{\star *}\end{array}$ & $\begin{array}{c}2.51462 \\
(11.78)^{\star *}\end{array}$ & $\begin{array}{l}7.98421 \\
(2.66)^{* *}\end{array}$ & $\begin{array}{l}3.81108 \\
(6.78)^{\star \star}\end{array}$ & $\begin{array}{c}6.2272 \\
(6.02)^{\star *}\end{array}$ & $\begin{array}{c}12.34229 \\
(1.58)\end{array}$ & $\begin{array}{l}4.88652 \\
(5.3)^{\star *}\end{array}$ & $\begin{array}{l}8.61146 \\
(3.75)^{\star \star}\end{array}$ & $\begin{array}{l}3.61687 \\
(6.81)^{* \star}\end{array}$ \\
\hline$S K$ & 0.38868 & -0.03273 & 0.12786 & 0.28395 & $\mathrm{n} / \mathrm{a}$ & 0.10206 & 0.17479 & -0.01885 & 0.09581 & 0.24506 & 0.1615 & 0.05299 \\
\hline KU & $\mathrm{n} / \mathrm{a}$ & 15.52784 & 12.43875 & $\mathrm{n} / \mathrm{a}$ & $\mathrm{n} / \mathrm{a}$ & 6.98832 & $\mathrm{n} / \mathrm{a}$ & 7.13074 & 9.1353 & 10.72751 & 5.71448 & $\mathrm{n} / \mathrm{a}$ \\
\hline $\log L$ & -4984.19 & -4571.21 & -4283.62 & -4946.5 & -5125.39 & -4589.18 & -4764.81 & -4324.27 & -4143.2 & -4539.15 & -4148.69 & -4871.91 \\
\hline LR-N. & $747.67^{\star *}$ & $510.65^{\star *}$ & $562.61^{* *}$ & $1770.18^{\star *}$ & $1909.21^{\star *}$ & $356.45^{\star *}$ & $435.13^{* *}$ & $411.35^{\star *}$ & $560.08^{* *}$ & $309.54^{* *}$ & $261.32^{\star *}$ & $782.88^{\star *}$ \\
\hline $\mathrm{R} 2$ & 0.05309 & 0.05044 & 0.06017 & 0.05387 & 0.02391 & 0.05059 & 0.06869 & 0.05425 & 0 & 0.06336 & 0.07138 & 0.0341 \\
\hline OBS & 3026 & 3026 & 3026 & 3026 & 3026 & 3026 & 3026 & 3026 & 2467 & 3026 & 3025 & 3026 \\
\hline
\end{tabular}

The estimated model is $R_{i, t}=\alpha_{i}+\beta_{i} R_{m, t}+\varepsilon_{i, t}$ where $\mathrm{R}_{\mathrm{i}, \mathrm{t}}$ and $\mathrm{R}_{\mathrm{m}, \mathrm{t}}$ are excess returns. The models were estimated with maximum likelihood using the SGT, SGED, EGB2, IHS, symmetric T, Laplace, and normal pdf s for each of the utilities. The estimations above were estimated using the SGT density specification of Equation (3). Parentheses include the T-values based on robust standard errors for the estimates. SK and KU are the sample skewness and kurtosis for the model residuals. LR-Normal is the log-likelihood ratio for testing the SGT against the normal pdf. It follows the $\chi^{2}$ distribution with 3 d.f. ${ }^{\star}$ Statistically significant at the $95 \%$ level. ${ }^{*}$ Statistically significant at the $99 \%$ level.

The results in Table 2 show that there is substantial leptokurtosis for every utility CAPM regression residuals with an available estimate of kurtosis. The value of the kurtosis parameter for the normal pdf is 3 . Kurtosis is not defined for the SGT with a value of $n<4$, therefore an estimate of kurtosis does not exist for every regression. $k$, a SGT kurtosis parameter, is significant for every estimation and $K U$ is also substantially larger than three for every utility estimation. $n$ is also a kurtosis parameter for the SGT and is significant for almost every utility CAPM estimation. This provides further evidence that $O L S$, where $k=2$, does not provide the best fit of the data.

The asymmetric model estimation results for the SGT are in Table 3. The asymmetry coefficient $\left(\beta_{i, n}=\beta_{i}^{-}-\beta_{i}^{+}\right)$which is equal to the difference between the up and down market betas, is positive and significant at the 99 percent level for all but two utilities. Therefore, electric utilities stock returns responses have an asymmetry where the down market betas are substantially larger than up market betas. This result suggests that the information signals in utility stock returns is evidence that regulation is stringent and that electric utility stock returns are responsive to down markets, meaning that they fall quickly in response to declines in the stock market total return, and have little response to rises in stock market returns. 
Table 3. Asymmetric response model sgtestimation results. Reprinted with permission from Taylor and Francis and R. A. Michelfelder [32], 2015. "Electric Utility Regulation and Investment in Green Energy Resources," Journal of Sustainable Finance \& Investment, 5, 48-64.

\begin{tabular}{|c|c|c|c|c|}
\hline \multirow{2}{*}{ Utility } & \multirow{2}{*}{$\beta_{i, n}=\left(\beta_{i}^{-}-\beta_{i}^{+}\right)$} & \multirow{2}{*}{ LR-Normal } & \multicolumn{2}{|c|}{ Regression Error Term } \\
\hline & & & Skewness & Kurtosis \\
\hline AEP & $0.63591^{* *}$ & $644.99^{* *}$ & 0.06714 & 20.09796 \\
\hline $\mathrm{CIN}$ & $0.47909^{* *}$ & $345.79^{* *}$ & 0.14922 & 6.78236 \\
\hline \multirow[t]{2}{*}{ CMS } & $0.33106^{* *}$ & $1383.21^{\star *}$ & & \\
\hline & $0.42911^{* *}$ & $566.34^{* *}$ & 0.13054 & \\
\hline DPL & $0.41650^{\star *}$ & $553.43^{\star \star}$ & 0.45028 & 42.55113 \\
\hline DTE & $0.65440^{* *}$ & $390.64^{\star *}$ & 0.16753 & 17.70259 \\
\hline DUK & $0.62964^{\star *}$ & $609.71^{\star *}$ & 0.08367 & 10.97236 \\
\hline $\mathrm{ED}$ & $0.74933^{\star *}$ & $216.75^{\star *}$ & 0.00737 & 7.20859 \\
\hline $\mathrm{EDE}$ & -0.00120 & $1081.50^{\star *}$ & 0.26244 & 11.34728 \\
\hline EIX & $0.64973^{\star *}$ & $2343.33^{* *}$ & & \\
\hline ETR & $0.51522^{\star *}$ & $631.41^{* *}$ & 0.28481 & \\
\hline FPL & $0.52046^{* *}$ & $631.53^{\star *}$ & 0.20061 & \\
\hline GMP & 0.00113 & $1901.47^{\star *}$ & 0.11253 & 23.29952 \\
\hline $\mathrm{HE}$ & $0.31769^{\star *}$ & $459.53^{* *}$ & 0.12574 & 20.51400 \\
\hline IDA & $0.34791^{* *}$ & $933.80^{* *}$ & 0.17406 & \\
\hline NI & $0.36974^{\star \star}$ & $704.70^{\star \star}$ & 0.26356 & 22.2486 \\
\hline NU & $0.34370^{* *}$ & $670.02^{* *}$ & 0.47053 & \\
\hline OGE & $0.36356^{* *}$ & $763.45^{\star *}$ & 0.41151 & 55.11190 \\
\hline PCG & $0.67678^{\star *}$ & $2558.41^{\star *}$ & & \\
\hline PEG & $0.61655^{\star *}$ & $461.34^{* *}$ & -0.17928 & 40.07774 \\
\hline PGN & $0.65285^{\star *}$ & $18,117.66^{* *}$ & 0.37742 & \\
\hline PNM & $0.42358^{* *}$ & $517.25^{\star *}$ & 0.44438 & 105.94479 \\
\hline PNW & $0.48876^{\star \star}$ & $1037.71^{\star *}$ & 0.31613 & \\
\hline POM & $0.38260^{* *}$ & $498.89^{* *}$ & 0.25469 & 30.87543 \\
\hline PPL & $0.32531^{\star *}$ & $736.91^{* *}$ & 0.39597 & 720.96758 \\
\hline PSD & $0.33936^{\star \star}$ & $509.28^{* *}$ & -0.04004 & 20.7707 \\
\hline SCG & $0.28571^{\star *}$ & $559.55^{\star \star}$ & 0.20312 & 14.26283 \\
\hline SO & $0.62606^{\star *}$ & $1817.25^{\star \star}$ & 0.32385 & \\
\hline SRP & $0.29644^{* *}$ & $1893.73^{* *}$ & & \\
\hline $\mathrm{TE}$ & $0.34318^{\star \star}$ & $345.94^{* *}$ & 0.15439 & 8.06323 \\
\hline TXU & $0.53978^{\star *}$ & $439.85^{\star *}$ & 0.03524 & \\
\hline UIL & $0.22461^{\star *}$ & $407.47^{\star *}$ & -0.01053 & 7.24365 \\
\hline UTL & 0.00032 & $659.85^{* *}$ & 0.20288 & 26.12142 \\
\hline WEC & $0.33071^{\star *}$ & $300.99^{\star *}$ & 0.29048 & 12.58194 \\
\hline WPS & $0.31888^{\star *}$ & $256.06^{* *}$ & 0.19964 & 5.60454 \\
\hline WR & $0.34982^{* *}$ & $787.05^{\star *}$ & 0.20040 & \\
\hline
\end{tabular}

${ }^{*}$ Statistically significant at $99.99 \%$. Missing skewness and kurtosis indicate that they are not defined for the SGT and do not exist. The results above are estimates of the model (Equation (2)) as shown below using the SGT density: $R_{i, t}=\alpha_{i}+\alpha_{n, i} D_{n, t}+\alpha_{r, i} D_{r, t}+\left(\beta_{i}+\beta_{i, n} D_{n, t}+\beta_{i, r} D_{r, t}\right) R_{m, t}+\mu_{i, t}$. 
Table 3 also shows the results of the likelihood ratio test comparing the fits of the SGT and normal pdf's of the regression errors. The likelihood ratios are $\chi^{2}$ distributed with three degrees of freedom. The $\chi^{2}$ tests show that the SGT provides a better fit for the regressions than OLS. All $\chi^{2}$ statistics are significant at the 99.99 percent level. Note once again that the regression residuals' skewness is generally positive and the kurtosis estimate indicates leptokurtic pdf's for the residuals.

If there were no asymmetry in utility stock returns responses in down and up markets, the coefficient would be insignificant. Table 3 suggests that there is a positive asymmetric response in utilities returns in down markets for all but two utilities The down market beta is significantly larger than the up market beta. These results do not support the notion of lax electric utility regulation. The results show that the down market betas are larger than the betas for normal market conditions and larger than up market betas. The results demonstrate asymmetry in returns but they do not support the hypothesis that utility returns have a strong up market response and weak down market response. Therefore, the information signal in stock returns provides evidence of stringent regulation.

Turning to the impact of deregulation on systematic risk, Table 4 displays the SGT estimation results for standard CAPM estimations in the pre- and post-deregulation periods as well the slope dummy variable coefficient for deregulation in the asymmetric response model. For the CAPM estimations, all utilities with non-zero betas had a significant drop in beta after deregulation. Additionally, the robust measure of beta changes, i.e., the slope dummy variable coefficient in the asymmetric model $\left(\beta_{i, r}\right)$ period shows a significant and consistent reduction in beta for 29 of 36 utilities and all of these slopes are significant at a minimum $95 \%$ level of significance.

The buffering impact is not supported by these results. An inspection of the variance of market returns in pre- and post-periods suggest that the volatility of the market rose more relative to utility returns to result in declining betas. Since 1996, the market had been ravaged at that time with problems such as the technology sector meltdown, a recession in the early 2000's, and investor confidence problems associated with corporate governance. This would result in a lower level of systematic risk for the utilities if the correlation coefficient remains the same but the ratio of the standard deviations of the utility stock to market returns falls. This can be seen by inspection of the beta:

$$
\beta_{i}=\frac{\rho_{i, m} \sigma_{i} \sigma_{m}}{\rho_{m}^{2}}=\frac{\rho_{i, m} \sigma_{i}}{\sigma_{m}}
$$

where $\rho_{i, m}=$ correlation coefficient of the utility stock $i$ and market returns, $\sigma_{i}$ is the standard deviation of utility $i$ 's returns and $\sigma_{m}$ is the market returns standard deviation. The $\sigma_{m}$ for the S \& P 500 daily total return was 0.723 for the pre-deregulation period and was 1.268 for the post deregulation period.

Consistent with Blinder and Norton [5], the concern arises that other variables effecting betas are not controlled. The results in that article show a strong 
Table 4. Table of Pre- and post-regulation betas and deregulation slope coefficient. Reprinted with permission from Taylor and Francis and R. A. Michelfelder [32], 2015. "Electric Utility Regulation and Investment in Green Energy Resources," Journal of Sustainable Finance \& Investment, 5, 48-64.

\begin{tabular}{|c|c|c|c|c|c|}
\hline Symbol & $1990-02$ & Pre-96 & Post-96 & $\Delta \beta$ & Dereg. Slope $\left(\beta_{r, i}\right)$ \\
\hline AEP & $0.3767^{\star *}$ & $0.5958^{\star *}$ & $0.2676^{* *}$ & -0.3327 & $-0.3319^{* *}$ \\
\hline CIN & $0.3620^{* *}$ & $0.4803^{* *}$ & $0.2859^{\star *}$ & -0.1936 & $-0.1957^{\star *}$ \\
\hline CMS & $0.2860^{* *}$ & $0.4446^{\star *}$ & $0.2299^{* *}$ & -0.2167 & $-0.2090^{\star *}$ \\
\hline $\mathrm{D}$ & $0.3550^{* *}$ & $0.4671^{\star *}$ & $0.2870^{\star *}$ & -0.1806 & $-0.1700^{* *}$ \\
\hline DPL & $0.3403^{* *}$ & $0.4836^{\star *}$ & $0.2786^{\star *}$ & -0.2059 & $-0.1892^{\star *}$ \\
\hline DTE & $0.4145^{\star *}$ & $0.6817^{\star *}$ & $0.3024^{\star *}$ & -0.3795 & $-0.3594^{* *}$ \\
\hline DUK & $0.4259^{* *}$ & $0.6035^{* *}$ & $0.3203^{* *}$ & -0.2851 & $-0.2865^{* *}$ \\
\hline ED & $0.4161^{\star *}$ & $0.7617^{\star *}$ & $0.2752^{\star *}$ & -0.4833 & $-0.4735^{\star *}$ \\
\hline EDE & $0.1581^{\star *}$ & 0.0006 & $0.2178^{\star *}$ & 0.2167 & $0.1405^{\star *}$ \\
\hline EIX & $0.4728^{\star *}$ & $0.6132^{\star *}$ & $0.3759^{\star *}$ & -0.2317 & $-0.2334^{* *}$ \\
\hline ETR & $0.3177^{\star \star}$ & $0.5667^{\star \star}$ & $0.1984^{\star \star}$ & -0.3683 & $-0.3647^{\star \star}$ \\
\hline FPL & $0.3333^{\star *}$ & $0.5296^{\star *}$ & $0.2283^{\star *}$ & -0.3013 & $-0.2905^{\star *}$ \\
\hline GMP & 0.0002 & 0.0021 & 0.0002 & 0.0000 & -0.0012 \\
\hline $\mathrm{HE}$ & $0.2489^{\star *}$ & $0.2895^{\star *}$ & $0.2363^{\star *}$ & -0.0590 & -0.0668 \\
\hline IDA & $0.2845^{\star *}$ & $0.3205^{\star *}$ & $0.2787^{\star *}$ & -0.0388 & -0.0319 \\
\hline NI & $0.2755^{\star *}$ & $0.3505^{\star *}$ & $0.2486^{\star *}$ & -0.1030 & $-0.1039^{\star}$ \\
\hline $\mathrm{NU}$ & $0.2669^{* *}$ & $0.4239^{* *}$ & $0.1935^{* *}$ & -0.2200 & $-0.1991^{* *}$ \\
\hline OGE & $0.2699^{\star *}$ & $0.3577^{\star \star}$ & $0.2376^{\star \star}$ & -0.1206 & $-0.1254^{\star *}$ \\
\hline PCG & $0.4541^{\star *}$ & $0.6932^{\star *}$ & $0.3100^{* *}$ & -0.3813 & $-0.3788^{\star *}$ \\
\hline PEG & $0.3984^{* *}$ & $0.6191^{\star *}$ & $0.2929^{* *}$ & -0.3348 & $-0.3249^{* *}$ \\
\hline PGN & $0.4020^{\star *}$ & $0.6364^{\star *}$ & $0.2990^{* *}$ & -0.3414 & $-0.3346^{* *}$ \\
\hline PNM & $0.3639^{\star *}$ & $0.5093^{\star *}$ & $0.3138^{\star *}$ & -0.1959 & $-0.1845^{\star \star}$ \\
\hline PNW & $0.2893^{\star *}$ & $0.5530^{* *}$ & $0.1874^{\star *}$ & -0.3644 & $-0.3793^{\star *}$ \\
\hline POM & $0.3374^{\star *}$ & $0.4240^{* *}$ & $0.2886^{\star *}$ & -0.1418 & $-0.1326^{* *}$ \\
\hline PPL & $0.3285^{\star \star}$ & $0.3310^{\star *}$ & $0.3267^{\star *}$ & -0.0058 & 0.0085 \\
\hline PSD & $0.2701^{\star *}$ & $0.3450^{\star *}$ & $0.2416^{\star *}$ & -0.1026 & $-0.0996^{\star}$ \\
\hline SCG & $0.2712^{\star *}$ & $0.3196^{\star *}$ & $0.2518^{\star *}$ & -0.0710 & $-0.0725^{\star}$ \\
\hline SO & $0.3853^{\star *}$ & $0.6699^{* *}$ & $0.2439^{\star *}$ & -0.4213 & $-0.3995^{\star *}$ \\
\hline SRP & $0.2788^{\star *}$ & $0.2685^{\star *}$ & $0.2875^{\star \star}$ & 0.0149 & 0.0032 \\
\hline $\mathrm{TE}$ & $0.2643^{\star \star}$ & $0.3599^{* *}$ & $0.2292^{\star *}$ & -0.1366 & $-0.1295^{\star \star}$ \\
\hline TXU & $0.3321^{\star *}$ & $0.4801^{\star *}$ & $0.2580^{* *}$ & -0.2233 & $-0.2308^{\star *}$ \\
\hline UIL & $0.2545^{\star *}$ & $0.2244^{\star *}$ & $0.2784^{\star *}$ & 0.0534 & 0.0414 \\
\hline UTL & 0.0000 & 0.0003 & 0.0368 & 0.0029 & 0.0003 \\
\hline WEC & $0.2900^{* *}$ & $0.3969^{\star *}$ & $0.2519^{\star *}$ & -0.1460 & $-0.1355^{* *}$ \\
\hline WPS & $0.2682^{\star \star}$ & $0.3307^{\star \star}$ & $0.2459^{\star *}$ & -0.0946 & $-0.0921^{* *}$ \\
\hline WR & $0.2519^{\star \star}$ & $0.3273^{\star *}$ & $0.2249^{\star *}$ & -0.1027 & $-0.1209^{\star *}$ \\
\hline Median & 0.3044 & 0.4373 & 0.2542 & -0.1871 & \\
\hline Mean & 0.3070 & 0.4293 & 0.2489 & -0.1804 & \\
\hline
\end{tabular}

${ }^{\star}$ Statistically significant at $95 \%$; ${ }^{*}$ Statistically significant at $99 \%$. 
association between falling betas and deregulation, albeit in the opposite direction proposed by Peltzman [14]. One possibility is that if utilities generally faced unfavorable regulation, as the results herein suggest, then less regulation may be perceived by investors as less risky than "profit protection" from adversarial regulatory agencies.

The Binder and Norton [5] asset beta model would suggest the result of a decline in fixed or variable cost, a rise in expected output, increasing electric prices, or buffering by the regulator. All of these effects on beta are effected by regulation. Another alternative could be that electric utilities have been divesting of generation assets due to regulatory requirements or the result of a strategic decision since it was the generation function that was deregulated. Generation is the business activity of a vertically integrated utility that creates the most risk for the utility. It requires the largest capital investment and faces the greatest chance of being excluded from rate base (excluded from earning a return in a regulated environment) in determining the revenue requirement due to "used and useful" tests by regulators. Generation units are built many years in advance based on forecasts of electric power demands. If a unit is deemed as excess capacity, its book value may be partially or completely excluded from rate base and no return is earned on that asset. Such regulatory problems occurred during periods of rising prices due to fuel costs, high inflation, and interest rates (the Joskow [8] effect). Also, wholesale generation is the only portion of the electric utility business that has been deregulated nationwide. This impact suggests that the regulatory buffering effect may be rising since as many utilities divested of their most risky assets under a historically regulated or newly deregulated regime.

A competing theory to the buffering hypothesis, Joskow and MacAvoy [30] asserted that regulatory lag increased risk as the regulatory process is slow to respond to changes in conditions that adversely affect utility profits. Therefore, deregulation would reduce the risk of the firm no longer subject to the regulatory process. This is a possible explanation for the results in the study. Fraser and Kannan [31] did a study on both the buffering and regulatory lag hypotheses and found no support for regulatory lags.

In a presentation of a utility beta study to the US Edison Electric Institute (electric utility research and lobbying institute) member companies by the Brattle Group [32] (The Brattle Group is a utility finance and economics consulting group based in Cambridge, MA that testifies on the cost of equity capital for public utilities.), they found that there has been a trend toward falling betas with deregulation with an industry beta falling from 0.45 in February 1989 to 0.2 by December 2003. There is more research to be done to affirm that buffering has increased with deregulation and the causes of this unexpected result.

\section{Conclusions}

This paper investigated the asymmetric response of utility stock price volatility for information signals of investors' perceptions of utility regulatory policy. Se- 
condly, it estimated the impact of wholesale deregulation on systematic risk, or, the buffering effect associated with deregulation. The results indicate that utility stock returns do respond asymmetrically to daily up and down markets and that the down market response of utility stock returns dominates. This direction of the asymmetry suggests that investors' perceptions of utility regulatory policy are stringent.

Furthermore, the impact of deregulation on utility stock returns was modeled with pre- and post-wholesale-deregulation estimates of systematic risk. This deregulation required that electric utilities open their bulk power transmission lines to alternative purveyors of electric power. Systematic risk decreased substantially with wholesale competition. The result leads to the notion that the buffering impact was swamped any of a number of possibilities effecting the industry or market. They include the relative risk of the market increased, the cost structure of utilities improved, utilities faced positive demand shocks, prices increased, or the utility industry divested generation to a level that reduced their investment risk.

Some policy implications of these results suggest that stringent or adverse regulation, which attempts to squeeze as much of the financial resources of the regulated utility for lower rates, increases the volatility of utility stocks, investment risk, and therefore the cost of common equity capital. Therefore, lax regulation or regulation that is favorable to investors by reducing risk may have a rate reducing impact as the costs of common equity are less due to lower investment risk. A future area for research is whether lax regulation with a lower cost of common equity capital results in relatively lower rates than in adverse regulatory jurisdictions.

\section{Acknowledgements}

This paper has benefited from many helpful comments of participants at the Rutgers University Center for Research in Regulated Industries Eastern Conference and the Annual Conference of the Multinational Finance Society. The author wishes to thank Panayiotis Theodossiou, Tim Mount, Gene Pilotte, John Broussard, Michael Crew and Uzi Yaari for helpful comments.

\section{Conflicts of Interest}

The author declares no conflicts of interest regarding the publication of this paper.

\section{References}

[1] Seeholzer, R. (2002) Meeting the New Corporate Governance and Disclosure Challenges in the Post-ENRON Environment. Edison Electric Institute, Presentation to the Center for Research in Regulated Industries, Mimeo.

[2] Roseman, E. and De Martini, P. (2003) In Search of Transmission Capitalists. The Public Utilities Fortnightly (April 1), 20-25.

[3] Averch, H. and Johnson, L. (1962) Behavior of the Firm Under Regulatory Con- 
straint. American Economic Review, 52, 1052-1069.

[4] Crew, M.A. and Kleindorfer, P. (1979) Public Utility Economics. Martin's Press, New York. https://doi.org/10.1007/978-1-349-03263-1

[5] Binder, J.J. and Norton, S.W. (1999) Regulation, Profit Variability and Beta. Journal of Regulatory Economics, 15, 249-265. https://doi.org/10.1023/A:1008078230272

[6] Nwaeze, E. (1998) Public Utility Regulation in the U.S. and Asymmetric Return Responses to Positive and Negative Abnormal Earnings. Multinational Finance Journal, 2, 269-293. https://doi.org/10.17578/2-4-2

[7] Davidson, W.N., Rangan, N. and Rosenstein, S. (1997) Regulation Systematic Risk in the Electric Utility Industry: A Test of the Buffering Hypothesis. The Financial Review, 23, 163-184. https://doi.org/10.1111/j.1540-6288.1997.tb00420.x

[8] Joskow, P.L. (1974) Inflation and Environmental Concern: Structural Change in the Process of Public Utility Regulation. Journal of Law and Economics, 17, 291-327. https://doi.org/10.1086/466794

[9] Joskow, P.L. (1973) Pricing Decisions of Regulated Firms: A Behavioral Approach. The Bell Journal of Economics, 4, 118-140. https://doi.org/10.2307/3003142

[10] Nwaeze, E. (2000) Deregulation of the Electric Power Industry: The Earnings, Risk, and Returns Effects. Journal of Regulatory Economics, 17, 49-67.

https://doi.org/10.1023/A:1008101304713

[11] Hirst, E. and Kirby, P. (2001) Electric Reliability: Potential Problems and Possible Solutions. Prepared for the Edison Electric Institute, Oak Ridge TN.

[12] Bawa, V., Brown, S. and Klein, R. (1981) Asymmetric Response Asset Pricing Models: Testable Alternatives to Mean-Variance. Mimeo.

[13] Pedersen, C.S. and Satchell, S.E. (2000) Small Sample Analysis of Performance Measures in the Asymmetric Response Model. Journal of Financial and Quantitative Analysis, 35, 425-450. https://doi.org/10.2307/2676212

[14] Peltzman, S. (1976) Towards a More General Theory of Regulation. Journal of Law and Economics, 19, 211-241. https://doi.org/10.1086/466865

[15] Ross, S.A. (1976) The Arbitrage Theory of Capital Asset Pricing. Journal of Economic Theory, 13, 341-360. https://doi.org/10.1016/0022-0531(76)90046-6

[16] Besanko, D., D'Souza, J. and Thiagarajan, S.R. (2001) The Effect of Wholesale Market Deregulation on Shareholder Wealth in the Electric Power Industry. Journal of Law and Economics, 44, 65-88. https://doi.org/10.1086/320268

[17] Chan, L.K.C. and Lakonishok, J. 1992) Robust Measurement of Beta. Journal of Financial and Quantitative Analysis, 27, 265-282. https://doi.org/10.2307/2331371

[18] Butler, R.J., McDonald, J.B., Nelson, R.D. and White, S. (1990) Robust and Partially Adaptive Estimation of Regression Models. Review of Economics and Statistics, 72, 321-327. https://doi.org/10.2307/2109722

[19] McDonald, J.B. and Nelson, R.D. (1989) Alternative Beta Estimation for the Market Model. Communications in Statistical Theory and Methods, 18, 4039-4058. https://doi.org/10.1080/03610928908830140

[20] Theodossiou, P. (1998) Financial Data and the Skewed Generalized t Distribution. Management Science, 44, 1650-1661. https://doi.org/10.1287/mnsc.44.12.1650

[21] Hansen, C.B., McDonald, J.B. and Theodossiou, P. (2007) Some Flexible Parametric Models for Skewed and Leptokurtic Data.

[22] McDonald, J.B., Michelfelder, R.A. and Theodossiou, P. (2009) Robust Regression Estimation Methods and Intercept Bias: A Capital Asset Pricing Model Application. 
Multinational Finance Journal, 13, 293-321. https://doi.org/10.17578/13-3/4-6

[23] McDonald, J.B., Michelfelder, R.A. and Theodossiou, P. (2010) Robust Estimation with Flexible Parametric Distributions: Estimation of Utility Stock Betas. Quantitative Finance, 10, 375-387. https://doi.org/10.1080/14697680902814241

[24] McDonald, J.B. and Michelfelder, R.A. (2017) Partially Adaptive and Robust Estimation of Asset Models: Accommodating Skewness and Kurtosis in Returns. Journal of Mathematical Finance, 7, 219-237. https://doi.org/10.4236/jmf.2017.71012

[25] The Value Line Investment Survey, "Ratings and Reports", March 8, 2002, April 5, 2002, and May 17, 2002.

[26] Harvey, C.R. and Siddique, A. (1999) Autogressive Conditional Skewness. Journal of Financial and Quantitative Analysis, 34, 465-487. https://doi.org/10.2307/2676230

[27] Harvey, C.R. and Siddique, A. (2000) Conditional Skewness in Asset Pricing Tests. Journal of Finance, 55, 1263-1295. https://doi.org/10.1111/0022-1082.00247

[28] Hein, S.E. and Westfall, P. (2004) Improving Tests of Abnormal Returns by Bootstrapping the Multivariate Regression Model with Event Parameters. Journal of Financial Econometrics, 2, 451-471. https://doi.org/10.1093/jjfinec/nbh018

[29] McDonald, J.B. and Newey, W.K. (1988) Partially Adaptive Estimation of Regression Models via the Generalized T Distribution. Econometric Theory, 4, 428-457. https://doi.org/10.1017/S0266466600013384

[30] Joskow, P.L. and MacAvoy, P. (1975) Regulation and the Financial Condition of the Electric Power Companies in the 1970’s. American Economic Review, 65, 295-301.

[31] Fraser, D.R. and Kannan, S. (1990) Deregulation and Risk: Evidence from Earnings Forecasts and Stock Prices. Financial Management, 19, 68-76.

https://doi.org/10.2307/3665611

[32] Michelfelder, R.A. (2015) Electric Utility Regulation and Investment in Green Energy Resources. Journal of Sustainable Finance \& Investment, 5, 48-64. https://doi.org/10.1080/20430795.2015.1050950

[33] Brattle Group (2004) Issues for Cost of Capital Estimation. Edison Electric Institute Conference, Chicago, 19 February 2004. 


\section{Appendix 1}

\begin{tabular}{|c|c|}
\hline Symbol & Utility Company Name \\
\hline AEP & American Electric Power \\
\hline CIN & Cinergy \\
\hline CMS & CMS Energy \\
\hline $\mathrm{D}$ & Dominion Resources \\
\hline DPL & Dayton Power and Light \\
\hline DTE & DTE Energy \\
\hline DUK & DUK Duke Power \\
\hline ED & Consolidated Edison \\
\hline $\mathrm{EDE}$ & Empire District \\
\hline EIX & Edison International \\
\hline ETR & Entergy \\
\hline FPL & Florida Power and Light \\
\hline GMP & Florida Public Service \\
\hline $\mathrm{HE}$ & Hawaii Electric \\
\hline IDA & Idaho Power \\
\hline NI & NiSource \\
\hline NU & Northeast Utilities \\
\hline OGE & Oklahoma Gas and Electric \\
\hline PCG & Pacific Gas and Electric \\
\hline PEG & Public Service Electric and Gas \\
\hline PGN & Progress Energy \\
\hline PNM & Public Service of New Mexico \\
\hline PNW & Pinnacle West \\
\hline POM & Potomac Electric Power Company \\
\hline PPL & Pennsylvania Power and Light \\
\hline PSD & Puget Power and Light \\
\hline SCG & SCANA Corp \\
\hline SO & Southern Companies \\
\hline SRP & Sierra Pacific Power \\
\hline $\mathrm{TE}$ & TECO Energy \\
\hline TXU & Texas Utilities \\
\hline UIL & United Illuminating \\
\hline UTL & Unitil Corp \\
\hline WEC & Wisconsin Electric \\
\hline WPS & WPS Resources \\
\hline WR & Western Resources \\
\hline
\end{tabular}

\section{Appendix 2}

The Bawa, Brown, Klein (1981) asymmetric response model can be re-written as follows:

$$
R_{i . t}=\alpha_{i}^{+} D_{t}^{+}+\alpha_{i}^{-} D_{t}^{-}+\beta_{i}^{+} R_{m, t}^{+}+\beta_{i}^{-} R_{m, t}^{-}+\varepsilon_{i, t}
$$


where $D_{t}^{+}=1$ for all positive excess returns and zero otherwise, $D_{t}^{-}=1$ for all negative returns and zero otherwise. Add and subtract both sides of the above equation by $\alpha_{i}^{+} D_{t}^{-}$and $\beta_{i}^{+} D_{n, t}$ and note

$$
R_{i, t}=\alpha_{i}^{+}\left(D_{t}^{+}+D_{t}^{-}\right)+\left(\alpha_{i}^{-}-\alpha_{i}^{+}\right) D_{t}^{-}+\beta_{i}^{+}\left(R_{m, t}^{+}+R_{m, t}^{-}\right)+\left(\beta_{i}^{-}-\beta_{i}^{+}\right) R_{m, t}^{-}+\varepsilon_{i, t}
$$

can be re-written as:

$$
R_{i . t}=\alpha_{i}+\alpha_{n, i} D_{n, t}+\beta_{i} R_{m, t}+\left(\beta_{i}^{-}-\beta_{i}^{+}\right) D_{n, t} R_{m, t}+\varepsilon_{i, t}
$$

or,

$$
R_{i, t}=\alpha_{i}+\alpha_{n, i} D_{n, t}+\left(\beta_{i}+\beta_{i, n} D_{n, t}\right) R_{m, t}+\varepsilon_{i, t} .
$$

In the above equation note that $D_{t}^{+}+D_{t}^{-}=1$ for all values of $r_{m, t}$ and $r_{m, t}^{-}=D_{n, t} r_{m, t}$. Additionally, $D_{t}^{-}$is re-written as $D_{n, t}$. The final model for estimating asymmetry and the impact of deregulation on returns includes the above model augmented with deregulation slope and intercept dummy variables, $D_{r, t}$ The final model is:

$$
R_{i, t}=\alpha_{i}+\alpha_{n, i} D_{n, t}+\alpha_{r, i} D_{r, t}+\left(\beta_{i}+\beta_{i, n} D_{n, t}+\beta_{i, r} D_{r, t}\right) R_{m, t}+\mu_{i, t}
$$

$\beta_{i, n}$ is the asymmetry coefficient and is the difference between the down and up market betas $\left(\beta_{i}^{-}-\beta_{i}^{+}\right)$, and $\beta_{i, r}$ is the coefficient that represents the change in beta due to deregulation and $\beta_{i}$ is the standard CAPM beta. It follows from the results for the above models that the intercept and slope of the model for the pre-deregulation period are respectively $\alpha_{i}$ and $\beta_{i}$ and for the post-deregulation period $\alpha_{i}+\alpha_{r, i}$ and $\beta_{i}+\beta_{r, i}$. In this respect, the coefficients $\alpha_{r, i}$ and $\beta_{r, i}$ show the change in the value of the intercept and slope dummies during the post deregulation period. Statistical significance of these coefficients will indicate that the parameters are different during the two periods. More specifically, a positive $\beta_{r, i}$ implies that the deregulation period is associated with an increase in systematic risk. 